\title{
Study on the overseas market selection of coal engineering enterprises
}

\section{based on the diamond model}

\author{
XU Zhong-hua',a \\ 1.School of Economics and Management ,Beijing Jiaotong University, Beijing 100044,China. \\ ahuar206@126.com
}

Key words: diamond model; coal engineering; overseas market; competitiveness

\begin{abstract}
Combined with the characteristics of international coal market itself, this paper establish the coal engineering enterprises diamond model in order to select overseas target market, quantify the various factors, set comprehensive assessment index system which including 6 first grade indices and 15 second grade indices, and determine the weights of assessment indices by the principle of analytic hierarchy process (AHP). Select the world's five major coal producing country, through a combination of quantitative and qualitative analysis, target market comparative diamond models are constructed under influencing factors to arrive at a composite score for each target market. the results showed that the elements of Indonesian market is relatively good for coal enterprises to enter; followed by Russia, Australia, and the Indian market, the U.S. market demand has a little growth, The most intense competition, and difficult to entre, the diamond model comprehensive evaluation index system can objectively reflect the competitiveness of the goal market, and provide a scientific basis for decision making of coal engineering enterprises to explore overseas markets.
\end{abstract}

\section{Introduction}

With the penetration and influence of global integration, the pace of "going out" has been quickened. More and more engineering enterprises will make full use of the two kinds of resources, with more and more projects in the international engineering market, high profitability and huge potential for development, and more engineering enterprises will make full use of the two kinds of resources and The two markets, which it have been promoted to the strategic level ${ }^{[1-4]}$, especially for coal engineering enterprises, with the shrinking of domestic coal infrastructure market in recent years, it has become an urgent and necessary choice for coal engineering enterprises to get involved in overseas markets ${ }^{[5]}$.

The choice of overseas target market is a complex system problem, and it is also the core risk of "going out". It not only involves the enterprise's own factors, but also is deeply influenced by many complex external factors ${ }^{[6]}$, it can be said that the overseas market has an attractive opportunity. There are many risks, especially most coal engineering enterprises lack the mature overseas project operation experience, It have certain blindness to the market entry, lack the market evaluation system, which cause many enterprises defeated to go out in the process. Therefore, how to correctly select the overseas target market has attracted more and more attention of coal engineering enterprises ${ }^{[7]}$.

The diamond model theory is a new method to understand the global competitive position of a country or a region. This paper analyzes the competitive position of the target market country by 
combining quantitative and qualitative analysis with the aid of diamond model theory. To coal engineering enterprises to open up overseas markets to provide a scientific basis for decision-making.

\section{The basic theory of diamond model}

Michael Porter, a famous strategic management scientist at Harvard University, put forward the diamond model theory in 1990. He concluded that the main reasons for winning the competitive advantage in the international competition of the industry of a particular country (region) are four basic influencing factors, that is, the factor of production. Demand conditions, related and supportive industries, corporate strategy and structure, and peer competition, as well as two auxiliary influencing factors, namely, opportunity and government, are linked together to form a famous diamond theory system, as shown in figure 1.

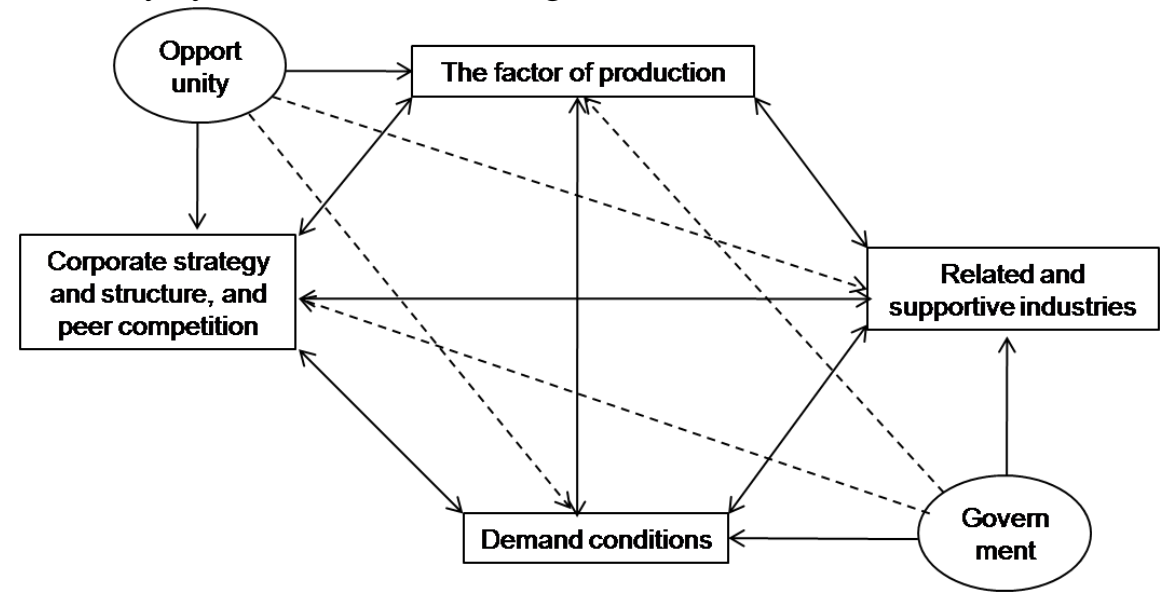

Fig.1 Signal of diamond theory

Among them, the factors of production are the basic conditions of a country, such as natural resources, education, infrastructure, etc. The related and supporting industries are the international competitiveness of these industries and related upstream and downstream industries, and the strategy and structure of the enterprises and the competition among the same industry are the strategies and structures of the enterprises and the performance of their competitors in this country. Opportunities come from major changes and breakthroughs in basic inventions, technology, war, political environment development, foreign market demand, etc. Government is the role of government policies in the development of enterprises ${ }^{[8-10]}$.

\section{Construction of Diamond Model for overseas Market selection of Coal Engineering Enterprises}

Construction of Comprehensive Evaluation Index system for Diamond Model.According to the principles of comprehensiveness, scientificalness, stratification and comparability, which should be followed in the design of evaluation index system ${ }^{[11]}$, the diamond model is revised according to the characteristics of overseas market selection of coal engineering enterprises. Based on the analysis of the influencing factors of the target market ${ }^{[12]}$, under the condition of considering the target market only, the strategy and structure of the enterprise and the competition of the same industry are revised to the same industry competition, and the six influential factors are set as the primary evaluation index. There are 15 secondary evaluation indexes, including 11 positive and 4 negative correlation indexes, which interact with each other and have strong 
coupling. Form a dynamic and complete comprehensive evaluation index system to objectively evaluate the competitiveness of overseas target markets, as shown in figure 2.

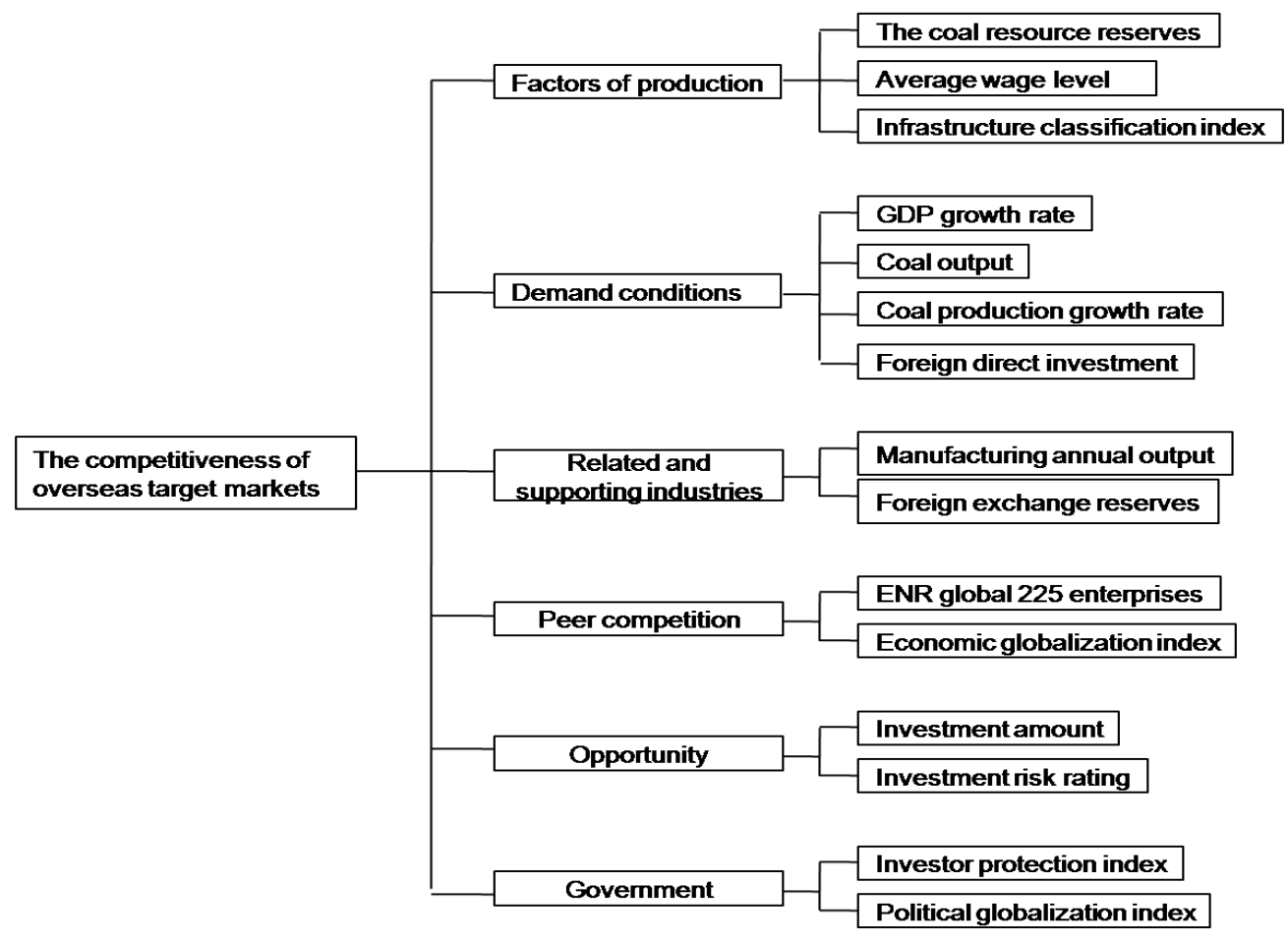

Fig.2 Comprehensive assessment index system of diamond model

I .Factors of production: the coal resource reserves, average wage level and infrastructure classification index of the target market etc,these 3 are mainly considered, among which the average wage level is a negative correlation index.

II .Demand conditions: mainly consider the target market GDP growth rate, coal output, coal production growth rate, foreign direct investment and other four evaluation indicators

III.Related and supporting industries: mainly consider the target market manufacturing annual output, foreign exchange reserves and other two evaluation indicators.

IV.Peer competition: mainly consider the target market ENR global 225 enterprises, economic globalization index and other two evaluation indicators, are all negative correlation indicators.

V .Opportunity: two evaluation indexes, such as investment amount and investment risk rating in the target market, are considered, among which the investment risk rating is a negative correlation index.

VI .Government: mainly consider the target market investor protection index, political globalization index and other two evaluation indicators.

Determination of the weight of Diamond Model Comprehensive Evaluation Index.After setting the evaluation index, because of the different importance of each index, it is necessary to determine the weight of each index. Below will use analytic hierarchy process (AHP) to calculate index weight. The Analytic hierarchy process (AHP) is a multi-objective decision analysis method combining qualitative and quantitative analysis, which provides a scientific quantitative processing method for determining the weight vector. The main steps are ${ }^{[13-15]}$ :

(1) The hierarchical structure model of the problem is established. The relationship between each index is determined and a multi-level index system is constructed.

(2) Construct pairwise judgment matrix. The index under the same factor in the system is compared according to the relative importance degree, and the influence degree of the index to the 
upper level is determined and quantified. The usual method is scale 1-9, as shown in Table 1. The results of pairwise comparisons are written as reciprocal matrices of order,

$$
\left[\begin{array}{ccccccc}
1 & \mathrm{~L} & x_{1 i} & \mathrm{~L} & x_{1 j} & \mathrm{~L} & x_{1 n} \\
\mathrm{M} & 1 & \mathrm{~L} & \mathrm{~L} & \mathrm{~L} & \mathrm{~L} & \mathrm{~L} \\
x_{i 1} & \mathrm{~L} & 1 & \mathrm{~L} & x_{i j} & \mathrm{~L} & x_{i n} \\
\mathrm{M} & \mathrm{L} & \mathrm{L} & 1 & \mathrm{~L} & \mathrm{~L} & \mathrm{~L} \\
x_{j 1} & \mathrm{~L} & x_{j i} & \mathrm{~L} & 1 & \mathrm{~L} & x_{j n} \\
\mathrm{M} & \mathrm{L} & \mathrm{L} & \mathrm{L} & \mathrm{L} & 1 & \mathrm{~L} \\
x_{n 1} & \mathrm{~L} & x_{n i} & \mathrm{~L} & x_{n j} & \mathrm{~L} & 1
\end{array}\right] \text {, among } x_{i j}=\frac{1}{x_{j i}} \text {, when } i=j, x_{j i}=x_{j i}=1 \text { 。 }
$$

\begin{tabular}{|c|c|c|c|c|c|}
\hline Importance degree & $\begin{array}{c}\text { equally } \\
\text { important }\end{array}$ & $\begin{array}{l}\text { Slightly } \\
\text { important }\end{array}$ & $\begin{array}{l}\text { Obviously } \\
\text { important }\end{array}$ & $\begin{array}{c}\text { Strong } \\
\text { importance }\end{array}$ & $\begin{array}{l}\text { Extremely } \\
\text { important }\end{array}$ \\
\hline equally important & 1 & $1 / 3$ & $1 / 5$ & $1 / 7$ & $1 / 9$ \\
\hline Slightly important & 3 & 1 & $1 / 3$ & $1 / 5$ & $1 / 7$ \\
\hline Obviously important & 5 & 3 & 1 & $1 / 3$ & $1 / 5$ \\
\hline Strong importance & 7 & 5 & 3 & 1 & $1 / 3$ \\
\hline Extremely important & 9 & 7 & 5 & 3 & 1 \\
\hline
\end{tabular}

Table1. Scale method of 1 to 9

The intermediate value of the two adjacent degree is $2,4,6,8$.

(3) Hierarchy Order Sort. All elements of this layer are given a priority for an element on the next layer. There are summation methods, product methods, root methods, feature vector methods, and so on .

(4) Hierarchical total ranking. The optimization order of the upper level or the total objective layer is further calculated by using the results of the hierarchical single order. At the same time, check the consistency,the formula is $C R=\frac{C I}{R I} \mathrm{p} 0.1$, among $C I$ is the consistency index of judgment matrix, The degree of deviation used to measure distance consistency, $C I=\frac{\lambda_{\max }-n}{n-1}, \lambda_{\max }$ Is the maximum eigenvalue of a matrix, $R I$ is determined the average random consistency index of a matrix, when $\mathrm{N}=1-9 \quad, \quad R I \quad$ is $0.00,0.00,0.52,0.90,1.12,1.24,1.32,1.41,1.46$, when $C R \mathrm{p} 0.1$, It can be considered that the judgment matrix has satisfactory consistency, otherwise the matrix needs to be adjusted. If the deviation exceeds the established threshold, the elements of the judgment matrix need to be readjusted. 。

The author made a questionnaire survey to the coal industry association and 20 industry experts about coal engineering enterprises, compared the importance of evaluation index, established the judgment matrix by the Analytic hierarchy process, and then carried out the hierarchical single sort and its consistency test. W The weights of the evaluation indicators are determined respectively, as shown in Table 2. 
Table2. Weight distribution of diamond model evaluation index system

\begin{tabular}{|c|c|c|c|}
\hline $\begin{array}{l}\text { primary evaluation } \\
\text { index }\end{array}$ & weight $w_{i}$ & Secondary evaluation index & weight $w_{i, j}$ \\
\hline \multirow{3}{*}{ production factors } & \multirow{3}{*}{0.0573} & Coal reserves & 0.5396 \\
\hline & & Average wage level & 0.2970 \\
\hline & & Infrastructure classification index & 0.1634 \\
\hline \multirow{4}{*}{ Demand condition } & \multirow{4}{*}{0.3568} & GDP rate of rise & 0.4413 \\
\hline & & Coal production & 0.0425 \\
\hline & & Coal productivity growth rate & 0.4544 \\
\hline & & Foreign direct investment & 0.0618 \\
\hline \multirow[t]{2}{*}{$\begin{array}{l}\text { Related and supporting } \\
\text { industries }\end{array}$} & \multirow[t]{2}{*}{0.0573} & $\begin{array}{l}\text { Annual output value of manufacturing } \\
\text { industry }\end{array}$ & 0.5000 \\
\hline & & foreign exchange reserve & 0.5000 \\
\hline \multirow[t]{2}{*}{ horizontal competition } & & ENR Number of Global 225 companies & 0.9000 \\
\hline & 0.3257 & Economic globalization index & 0.1000 \\
\hline \multirow[t]{2}{*}{ opportunity } & 0.1457 & China's investment & 0.8750 \\
\hline & & Investment risk rating & 0.1250 \\
\hline \multirow[t]{2}{*}{ government } & 0.0573 & Investor protection index & 0.5000 \\
\hline & & Political globalization index & 0.5000 \\
\hline
\end{tabular}

\section{Empirical research}

Taking the overseas market selection of a large domestic coal engineering enterprise as an example, using the modified diamond model and its evaluation index proposed in this paper, the market index data of the corresponding target market are calculated. Focus on exploring the general rules of overseas target market selection for Chinese coal engineering enterprises.

Brief introduction of Computational Model. $\mathrm{H}$ enterprise is a coal engineering company established by a large backbone of grade a reconnaissance and design research institute under the former ministry of coal industry. The company has more than 20 grade a qualification certificates and has the ability of engineering business in all professional fields of coal The company has been awarded many times at the national or provincial level. The company will position the overseas market as the long-term development strategy of the enterprise. In order to win in the fierce international market competition, it is necessary to systematically analyze and calculate the overseas market. In order to make scientific decision on the choice of target market.

Selection of target market. The target market is America, Australia, Indonesia, India, Russia and other major coal producing countries ${ }^{[16]}$. The target market covers four continents. There are developed and developing countries with strong representation.

Determination of calculation parameters. According to the diamond model index system, this paper selects the relevant data of the target market of the five major coal producing countries. The data are mainly from BP world energy statistics yearbook, world statistics yearbook and 2011 china foreign direct investment statistics annual report The UNCTAD FDI database, the IMF IFS database, etc., as shown in Table 3. 
Table 3. The relevant original data of the model

\begin{tabular}{|c|c|c|c|c|c|}
\hline index & America & Australia & $\begin{array}{c}\text { Indonesi } \\
\mathrm{a}\end{array}$ & India & Russia \\
\hline Reserves of coal resources (millions of tons) & 237295 & 76400 & 5529 & 60600 & 157010 \\
\hline Average wage (RMB / month) & 24921 & 20377 & 685 & 434 & 3868 \\
\hline Infrastructure classification index & 5.12 & 5.75 & 4.74 & 4.26 & 4.79 \\
\hline GDP growth rate $(\%)$ ) & 2.21 & 3.58 & 6.23 & 3.99 & 3.40 \\
\hline $\begin{array}{c}\text { Coal production (millions of tons of oil } \\
\text { equivalent) }\end{array}$ & 515.9 & 241.1 & 237.4 & 228.8 & 168.1 \\
\hline Coal capacity growth rate $(\%)$ & -7.5 & 4.2 & 9.0 & 5.8 & 6.1 \\
\hline Foreign direct investment (US \$100 million) & 2269.37 & 413.17 & 189.06 & 315.54 & 528.78 \\
\hline $\begin{array}{l}\text { Annual output of manufacturing (billions of US } \\
\text { dollars) }\end{array}$ & 17794.74 & 929.56 & 1425.33 & 1923.55 & 1619.58 \\
\hline Foreign exchange reserves (billions of dollars) & 518.8 & 360.0 & 1036.1 & 2629.3 & 4411.6 \\
\hline Number of ENR Global Top 225 companies & 57 & 5 & 0 & 4 & 3 \\
\hline Economic globalization index & 60.83 & 76.26 & 60.96 & 43.73 & 54.56 \\
\hline Investment in China (US $\$ 10,000$ ) & 181142 & 316529 & 59219 & 18008 & 71581 \\
\hline Investment risk rating & $4 / 9$ & $2 / 9$ & $7 / 9$ & $6 / 9$ & $6 / 9$ \\
\hline Investor protection index & 8 & 6 & 6 & 5 & 6 \\
\hline Political globalization index & 92.47 & 91.77 & 87.10 & 91.98 & 85.69 \\
\hline
\end{tabular}

Mathematical model solution. First of all, the above data is transformed by a percent linear transformation., Set up the $x_{i, j, k}$, It is $i$ that the first level evaluation indicator under the $j$ secondary evaluation indicator, corresponds to the original data for the $k$ country

Standard score for positive correlation factors:

$$
Q_{i, j, k}=\frac{x_{i, j, k}}{\max x_{i, j, k}} \times 100 \%
$$

Standard score for negative correlation factors:

$$
Q_{i, j, k}=\frac{\min x_{i, j, k}}{x_{i, j, k}} \times 100 \%
$$

The standard score of the two-level index system of the model is obtained, and the matrix transformation of the weight $w_{i, j}$ of the two-level evaluation index is carried out, and the score of the first-grade evaluation index is obtained as follows:

$$
Q_{i, k}=w_{i, j} Q_{i, j, k}
$$

As shown in table 4. 
Table 4. Elements standard score of the mode

\begin{tabular}{cccccc}
\hline primary evaluation index & America & Australia & Indonesia & India & Russia \\
\hline production factors & 100 & 49.76 & 48.6 & 80.53 & 76.27 \\
\hline Demand condition & 28.34 & 53.97 & 100 & 65.5 & 62.7 \\
\hline $\begin{array}{c}\text { Related and supporting } \\
\text { industries }\end{array}$ & 31.2 & 9.04 & 24.64 & 60.66 & 100 \\
\hline horizontal competition & 8.16 & 44.68 & 100 & 66.33 & 67.24 \\
\hline opportunity & 56.33 & 100 & 19.94 & 9.15 & 23.95 \\
\hline government & & & & 80.99 \\
\hline
\end{tabular}

The weighted value of the primary evaluation index is summed up, that is, the total score of the five target markets is obtained:

$$
\begin{aligned}
& Q_{k}=w_{i} Q_{i, k}=\left[\begin{array}{llllll}
w_{1} & w_{2} & w_{3} & w_{4} & w_{5} & w_{6}
\end{array}\right] \times\left(\begin{array}{ccc}
Q_{1,1} & \mathrm{~K} & Q_{1,5} \\
\mathrm{M} & \mathrm{O} & \mathrm{M} \\
Q_{6,1} & \mathrm{~L} & Q_{6,5}
\end{array}\right) \\
& =\left[\begin{array}{llllll}
33.05794 & 54.18988 & 75.98729 & 54.28911 & 56.92517
\end{array}\right]
\end{aligned}
$$

The United States, Australia, Indonesia, India, Russia score is repective 33.05794、54.18988、75.98729、54.28911、56.92517, Through the above calculation, it can be concluded that among the five countries mentioned above, the Indonesian market is the best target market for coal engineering, followed by Russia, India and Australia, because the US coal capacity growth rate index is negative. The space of coal engineering market is narrowed, and the American coal engineering market is a mature engineering market. The competition of large engineering companies in various countries in the United States is fierce, so it is more difficult to enter the coal engineering market.

\section{Summary}

At present, the international competitiveness of coal engineering enterprises in our country is not strong, and the overseas business is still in the primary stage, which is difficult and risky, so it is necessary to push forward the internationalization strategy. Based on the diamond model, this paper constructs the diamond model of the overseas target market of coal engineering enterprises, and determines its evaluation index, forms a relatively perfect comprehensive evaluation index system, and makes an empirical analysis of the five target markets. The priority of entry is determined. It is shown that the comprehensive evaluation index system of the diamond model can objectively reflect the competitiveness of each target market and provide a scientific decision basis for coal engineering enterprises to open up overseas markets.

\section{References}

[1]Lu Jinyong. The strategy of "going out" with the rise of the Multi-National Corporation in China-- the only way towards economic power [M].Beijing: Capital University of Economics \& Business Press, 2012:8-16.

[2]Wei Zhicheng. Study on measures to improve the competitiveness of our international engineering contracting enterprises[D]. Beijing: University of International Business and Economics, 2005:15-32. 
[3]Zhao Hui. Thoughts on the construction of the international engineering company of coal survey and design enterprises[J].Coal Engineering, 2011:127-128.

[4]Gu Weidong, Xie Tao. Risk and law precautions faced in oversea market[J].Legal \& Economy, 2007:16-17.

[5]Huang Shengchu, Liu Wenge, Sun Qinggang, Lan Xiaomei. Study on the internationalization strategy and analysis of overseas coal investment direction of China's coal enterprise[J].China Coal,2013:6-11.

[6]Liu Yingqi. Study on the Overseas Market Choice Model of Chinese Engineering Contractor[J]. CHINA SOFT SCIENCE,2004:77-82.

[7] QiaoYongpu, Research on Asian coal engineering target market selection of CCTEG[D]. Beijing: Beijing Jiaotong University, 2011:49-53.

[8] Michael E. Porter. The Competitive Advantage of Nations[M]. Beijing: Hua Xia Publishing House. 2002: 66-136.

[9]Dunning, John H. Internationalizing Porter's Diamond. Management International Review, Second Quarter 1993; 33, 2, 7-15.

[10]Su Na. The Study of the Competitiveness of Service Outsourcing among BRIC --Comparative Analysis Based on Diamond Model[J].West Forum,2012: 63-70.

[11]SuWeihua. Research on theory and method of multi index comprehensive evaluation[D].Fujian, Xiamen University,2000:18-19.

[12]Xu Weili, Du Bo.Analysis of the factors influencing the choice of foreign market entry mode of international engineering company[J]. International Economic Cooperation, 2010: $65-70$.

[13]Zhang Wenjie, Li Xuewei, Zhang Keming. Management Operations Research[M]. Beijing: China Railway Publishing House,2010: 423-427.

[14]Wang Ying, Deng Xuefeng. Evaluation system and method of supply chain management maturity [J]. Journal of China Coal Society, 2007:1340-1344.

[15] Liu Guoxin, Yan Junzhou. A Study on the Construction of GEMS Model to Evaluate the Competitiveness of Industrial Cluster[J].Science \& Technology Progress and Policy,2010:105-108.

[16]BP Statistical Review of World Energy. 